\title{
Mammographic Density and Vitamin D Levels - A Cross-sectional Study
}

\section{Mammografische Dichte und Vitamin-D-Spiegel - eine Querschnittsuntersuchung}

Authors

Loreen Straub ${ }^{1,2}$, Johanna Riedel ${ }^{1}$, Peter B. Luppa ${ }^{3}$, Johanna Wissing ${ }^{1}$, Almut Artmann ${ }^{4}$, Marion Kiechle ${ }^{1}$, Vanadin Regina Seifert-Klauss ${ }^{1}$

\author{
Affiliations \\ 1 Klinik und Poliklinik für Frauenheilkunde, Technische Universität \\ München, München, Germany \\ 2 Harvard T.H. Chan School of Public Health, Boston, MA, USA \\ 3 Institut für Klinische Chemie und Pathobiochemie, \\ Technische Universität München, München, Germany \\ 4 Praxis für Brustgesundheit, München, Germany
}

Key words

Vitamin D, breast density, BMI, age, menopausal status

Schlüsselwörter

Vitamin D, Brustdichte, BMI, Alter, Menopausenstatus

$\begin{array}{ll}\text { received } & 22.11 .2016 \\ \text { revised } & 30.1 .2017 \\ \text { accepted } & 31.1 .2017\end{array}$

\section{Bibliography}

DOI http://dx.doi.org/10.1055/s-0043-102694

Geburtsh Frauenheilk 2017; 77: 257-267 @ Georg Thieme Verlag KG Stuttgart · New York | ISSN 0016-5751

\section{Correspondence}

Dr. Vanadin Regina Seifert-Klauss, MD PhD

Klinik und Poliklinik für Frauenheilkunde,

Technische Universität München, Klinikum rechts der Isar Ismaninger Straße 22, 81675 München, Germany

vanadin.seifert-klauss@tum.de

Deutsche Version unter:

http://dx.doi.org/10.1055/s-0043-102694

\section{ABSTRACT}

Background Some studies have already proposed an inverse association between vitamin $D$ levels and breast density. As breast density is already considered an established risk factor for breast cancer, such a connection could offer a new starting point for the prevention of breast cancer.

Material and Methods To investigate this suggested connection, a total of 412 pre- and 572 post-menopausal women for whom mammography was indicated were recruited into this cross-sectional study. In addition to a questionnaire-based interview on the patient's general and gynecological medical history, her eating habits and lifestyle, serum levels of 25-hydroxyvitamin D [25(OH)D], calcium, phosphate and creatinine were determined. Breast density was determined by mammography and categorized as 1 to 4 according to the ACR classi- fication. In addition to performing descriptive analysis to get a better overview of the data, a number of multivariate regression models were developed to determine the impact of confounders and the connection between vitamin $\mathrm{D}$ and mammographic density.

Results More than half of all participants had low levels of 25(OH)D $(<20 \mathrm{ng} / \mathrm{ml})$ and only a small minority of women $(5.7 \%)$ had what are currently considered to be optimal serum levels of 25(OH)D of at least $30 \mathrm{ng} / \mathrm{ml}$. The significant majority of the cohort had a medium mammographic density ( $n=463$ had ACR 2; $n=343$ had ACR 3). Logistic regression analysis showed that lower $25(\mathrm{OH}) \mathrm{D}$ serum levels were associated significantly more often with high rather than medium breast density. This association remained, even after adjusting for other factors which influence breast density such as age, BMI and menopausal status ( $p=0.032$ for ACR 4 vs. ACR 2; $p=0.028$ for ACR 4 vs. ACR 3). When the same analysis was done separately for pre-menopausal and post-menopausal women, BMI in both groups was found to be inversely correlated with breast density and this inverse correlation was highly significant. In post-menopausal women, age was found to be similarly correlated while 25(OH)D did not appear to be associated with ACR. In pre-menopausal women the opposite was the case: although there was no correlation between age and breast density, higher vitamin $D$ levels tended to be associated with lower breast density ( $p=0.06$ for ACR 2 vs. ACR 4$)$ in this smaller sample $(n=412)$. When vitamin $D$-rich food and food supplements were also taken into account, regular intake of vitamin D preparations was associated with lower breast density; this association achieved borderline statistical significance ( $p=0.05$ for ACR 3 vs. ACR 4). When the analysis also took menopausal status into account, the breast density of pre-menopausal women was lower following regular vitamin $\mathrm{D}$ intake and this lower breast density of pre-menopausal women was statistically highly significant ( $p<0.001$ for ACR 1 and ACR 2 vs. ACR 4, respectively). This effect was not found in post-menopausal women. Frequent intake of vitamin D-containing nutrition had no significant impact on ACR in either of the groups.

Conclusion These results reinforce the assumption previously proposed by several authors that higher levels of $25(\mathrm{OH}) \mathrm{D}$ pre-menopause and vitamin $\mathrm{D}$ substitution are associated with lower breast density and could reduce the risk of breast cancer. The findings did not confirm any post-menopausal association between vitamin $D$ and mammographic breast density.

\section{ZUSAMMENFASSUNG}

Hintergrund In einigen Studien wurde bereits eine inverse Assoziation zwischen Vitamin D und Brustdichte diskutiert. Da die Brustdichte wiederum als etablierter Risikofaktor für Brustkrebs gilt, könnte ein derartiger Zusammenhang einen neuen Ansatzpunkt in der Prävention von Brustkrebs darstellen.

Material und Methoden Um der obigen Vermutung auf den Grund zu gehen, wurden im Rahmen dieser Querschnittstudie 412 prä- und 
572 postmenopausale Frauen mit einer Indikation zur Mammografie rekrutiert. Neben einem fragebogengestützten Interview zu allgemeiner und gynäkologischer Anamnese sowie zu Ernährungs- und Lebensgewohnheiten erfolgte eine Serumwertbestimmung von 25-Hydroxyvitamin D [kurz: 25(OH)D], Calcium, Phosphat und Kreatinin. Die mammografisch ermittelte Brustdichte wurde in die Kategorien 1 bis 4 nach ACR-Klassifikation eingeteilt. Neben einer deskriptiven Analyse zur besseren Übersicht des Datenmaterials wurden diverse multivariate Regressionsmodelle erstellt, mit deren Hilfe der Einfluss von Confoundern sowie der Zusammenhang zwischen Vitamin D und mammografischer Dichte erfasst werden sollte.

Ergebnisse Mehr als die Hälfte aller Teilnehmerinnen wiesen einen 25(OH)D-Mangel $(<20 \mathrm{ng} / \mathrm{ml})$ auf und nur ein geringer Anteil der Frauen (5,7\%) zeigte einen nach aktuellem Kenntnisstand optimalen 25(OH)D-Serumspiegel von mindestens $30 \mathrm{ng} / \mathrm{ml}$. Die deutliche Mehrheit des Kollektivs hatte eine mittlere mammografische Dichte ( $n=463$ mit ACR 2 und $n=343$ mit ACR 3). In der logistischen Regressionsanalyse ergab sich, dass niedrigere 25(OH)D-Serumspiegel signifikant häufiger mit einer hohen statt mit einer mittleren Brustdichte einhergingen. Dieser Zusammenhang blieb auch nach Adjustierung für weitere Einflussfaktoren der Brustdichte, wie Alter, BMI und Menopausenstatus, bestehen ( $p=0,032$ für ACR 4 vs. ACR 2; $p=0,028$ für $A C R \quad 4$ vs. ACR 3). Führte man die gleiche Analyse für prä- und postmenopausale Frauen getrennt durch, so korrelierte der BMI in beiden Gruppen hochsignifikant invers mit der Brustdichte. Bei postmenopausalen Frauen zeigte auch das Alter eine derartige Korrelation, wohingegen 25(OH)D nicht mit ACR assoziiert schien. Prämenopausal verhielt es sich umgekehrt: Zwar fand sich hier kein Zusammenhang zwischen Alter und der Brustdichte, jedoch ging ein höherer Vitamin-D-Spiegel tendenziell mit einer geringeren Brustdichte einher ( $p=0,06$ für ACR 2 vs. ACR 4) bei kleiner Stichprobe $(n=412)$. Bei zusätzlicher Berücksichtigung von Vitamin-D-reicher Nahrung und Nahrungsergänzungsmitteln war eine regelmäßige Vitamin-D-Präparateinnahme knapp signifikant mit einer niedrigeren Brustdichte assoziiert ( $p=0,05$ für ACR 3 vs. ACR 4). Unterschied man auch hier nach Menopausenstatus der Probandinnen, so fand sich prämenopausal eine hochsignifikant erniedrigte Brustdichte bei regelmäßiger Vitamin-D-Präparateinnahme ( $p<0,001$ für ACR 1 bzw. ACR 2 vs. ACR 4). Postmenopausal konnte dieser Effekt nicht beobachtet werden. Ein häufiger Konsum Vitamin-D-haltiger Nahrungsmittel zeigte bei beiden Gruppen keinerlei signifikanten Einfluss auf ACR.

Schlussfolgerung Diese Ergebnisse bestärken die bereits von einigen Autoren geäußerte Annahme, dass vor allem prämenopausal höhere 25(OH)D-Spiegel sowie eine Vitamin-D-Substitution mit einer niedrigeren Brustdichte einhergehen und damit auch eventuell zu einer Reduktion des Brustkrebsrisikos führen können. Eine postmenopausale Assoziation von Vitamin D und mammografischer Brustdichte bestätigte sich nicht.

\section{Introduction}

In recent years there has been a growing public focus on vitamin $D$ and its effect on processes in the human body; the number of publications on this topic continues to grow [1]. Vitamin D is not just responsible for regulating calcium levels, it also has a wide range of immunological and anti-proliferative effects. Because of these additional pleiotropic functions, the potential role of vitamin $D$ in reducing the risk for various epithelial cancers including the risk for breast cancer is currently being discussed [2].

Vitamin $\mathrm{D}$ is a prohormone which can be ingested enterally but is predominantly produced by the body itself with the help of sunlight. The term "vitamin" is therefore wrong in the proper sense of the word, as true vitamins are exclusively supplied through food intake. The first step in producing vitamin $D$ occurs in the liver where cholesterol is converted into 7-DHC (7-dehydrocholesterol) [3]. After transportation to the skin it is converted into vitamin $D_{3}$ (cholecalciferol) with the help of UVB radiation [4]. Cutaneous vitamin $D_{3}$ synthesis increases exponentially according to the amount of sunlight in the sky, and in the northern hemisphere it reaches its maximum during the summer months [5]. During this period and depending on the time spent outdoors, skin type, and location, the skin is the main supplier of vitamin D in our body, with up to 90 percent of vitamin D created by dermal synthesis. The intake of foodstuffs containing vitamin $D_{3}$ such as fish, mushrooms and dairy products also contributes to the provision of vitamin $D_{3}$; particularly in winter this can be important for vitamin $D$ metabolism.

Ingested or synthesized vitamin $\mathrm{D}_{3}$ is hydroxylated in the liver to 25-hydroxyvitamin D [25(OH)D, calcidiol] [6,7]. Calcidiol is then transported to the kidneys and other tissues mainly via the bloodstream where it is converted into its biologically active metabolite, 1,25-dihydroxyvitamin D (calcitriol) [6, 8]. Calcitriol binds to intracellular vitamin $D$ receptors and through complex formation encodes VDR proteins, which play an important role in inducing cell differentiation and apoptosis as well as for the inhibition of cell proliferation and angiogenesis. This suggests that through this mechanism apoptosis in cancer cells or precancerous cells could be driven. This might prevent uncontrolled cell proliferation.

The breast epithelium appears to belong to the group of tissues affected by vitamin D and VDR [6, 8-10]. Empirical research has already shown an inverse association between vitamin $D$ serum levels and the risk for breast cancer [10-16]. However, other studies found no correlation [17-19]. Results of studies which predominantly focused on vitamin $D$ intake through nutrition and its impact on breast cancer risk were also inconsistent [20].

Through its impact on breast epithelial cells it is possible that vitamin D might not just have a direct impact on breast cancer risk but also on breast density. A higher mammographic breast density is caused by an increased proportion of epidermal and stromal cells compared to adipose tissue. As an increased proliferation of stromal and epithelial tissue does not only result in higher breast density but is also associated with a greater potential for malignant transformation [21], there is reason to suspect that there could be an association between higher breast density and increased risk for breast cancer. Based on these considerations, some research teams have already begun to focus on the consequences of daily vitamin D supplements on mammographic breast density as a factor for breast cancer risk. Unfortunately, the results were again very mixed [22-26]. As far as the authors of this paper know, there has been little research into the effect 
of 25-hydroxyvitamin D serum levels on mammographic breast density - and the results were again highly inconsistent [26, 27].

Therefore, the aim of this cross-sectional study of 984 subjects was to investigate to what extent vitamin D serum levels correlated with mammographic breast density and which additional factors could potentially influence both of these parameters. Details of the study together with a comparison of women with malignant with women with benign findings in their mammography have already been published [28].

\section{Patients and Methods}

Following a positive vote by the Ethics Committee of the Technical University of Munich, 1104 women aged from 20 to 88 years were recruited into the study. Of these, 984 underwent mammography to determine breast density. The patient population consisted of asymptomatic women, women with suspicious findings on palpation, and women with a genetic risk of developing breast cancer over the longer term of at least 30 percent, including carriers of BRCA1/BRCA2 gene mutations [29].

Women who were pregnant, women who were breastfeeding, women who had undergone breast augmentation with implants, and women who had a history of breast cancer or who had undergone breast surgery for B3 lesions were excluded from the study.

\section{Patient characteristics and history}

A short questionnaire-based interview was carried out to obtain the patient's general medical and gynecological history and to record any known risk factors for breast cancer along with the patient's lifestyle and eating habits. Collected data included information on age and body mass index (BMI), alcohol and nicotine intake and any chronic disease. The documented data also included information on reproductive factors such as age at menarche, pregnancies, menopausal status, and hormone replacement therapy and whether the patient had had an ovariectomy. Women were classified as post-menopausal according to the WHO definition if their last spontaneous menstruation had occurred at least twelve months previously and cessation of bleeding had been caused by the loss of or decrease in ovarian endocrine function and was not the result of hysterectomy. Previous breast surgeries and any familial history of breast or ovarian cancer were recorded and particulars regarding the intake of vitamin D-rich food (dairy products, fish, etc.), the intake of calcium and vitamin D preparations as well as physical activity, the length of time spent outside, and the use of sun screen products were also recorded.

After completing the interview $7.5 \mathrm{ml}$ venous blood was taken to determine serum concentrations of $25(\mathrm{OH}) \mathrm{D}$, calcium, phosphate and creatinine. Vitamin D levels were determined using VD3 (Vitamin D3) RIA kits (DiaSorin S. p. A.).

To avoid strong seasonal fluctuations which peak during the summer months the test subjects were exclusively recruited from October to June.

\section{Mammography}

Two-plane mammography was carried out using standard mammography units. Mammography was not done for the purposes of the study, and in most patients $(n=920)$ it was usually performed on the day of the interview. The images were evaluated with regard to architectural distortion, micro-calcifications and focal lesions and classified using BI-RADS categories 0-6. Breast parenchymal density was classified into categories 1 to 4 using the ACR classification.

All mammograms were created using the same technology, stored on digital plates and evaluated by two separate investigators. All participants in the study had standard two-plane mammography (cranio-caudal [CC] and mediolateral oblique [MLO]), with additional special imaging done as required. Two radiologists evaluated the mammographic density using the BI-RADS Standard Atlas. This classifies breast density into four groups: ACR 1 (almost entirely fatty breast tissue or glandular tissue $<25 \%$ ), ACR 2 (scattered areas of fibroglandular density or $25-50 \%$ glandular tissue), ACR 3 (heterogeneously dense breast or $50-75 \%$ glandular tissue) and ACR 4 (extremely dense breast or glandular tissue $>75 \%$ ).

Abnormal mammographic findings were evaluated by histopathology and biopsy results were provided in writing.

\section{Statistical analysis}

SPSS was used to calculate the measures of locality and variation of the individual characteristics as well as their correlation with mammographic density based on the ACR classification and vitamin D serum levels. T-tests for independent samples were used to investigate statistically significant differences in mean values for 25(OH)D.

Multinomial logistic regression analysis was used to investigate the impact of different factors on breast density. Parameters which already correlated with ACR in descriptive statistical analysis and which also showed a significant correlation with ACR in regression analysis were summarized as "main confounders" in Model 1 ( $\triangleright$ Table 3 ). This included age, menopausal status and $\mathrm{BMI}$ as well as $25(\mathrm{OH}) \mathrm{D}$ levels to investigate the central question of this study. All subsequent logistic models were based on Model 1 and took other additional potential confounders into consideration. These included blood parameters, eating habits and lifestyle, prior breast surgery, familial risk, reproductive parameters and chronic disease. The resulting regression coefficients (B) correspond to logarithmic odds. Odds are calculated by dividing the probability of occurrence ( $p$ ) of an event by its converse probability (1-p). In our analysis, 1-p corresponded to the probability that the respective independent variable was in ACR category 4. Probability of occurrence $\mathrm{p}$ described the probability of the variable being in ACR categories 1, 2 or 3. The level of significance was set as $\alpha=0.05$.

\section{Results}

The mean serum concentration of $25-\mathrm{OH}$ vitamin $\mathrm{D}$ for the total patient population was $17.2 \mathrm{ng} / \mathrm{ml}$. Two of three women $(\mathrm{n}=652)$ were vitamin $\mathrm{D}$ deficient $(<20 \mathrm{ng} / \mathrm{ml})$ and only $6 \%$ had 
- Table 1 Mean vitamin D levels by the time of blood sampling by exogenous supply of vitamin D, weight category, extent of sports activity, time spent outdoors, and indication for biopsy based on mammographic findings. The mean 25(OH)D levels are shown together with their standard deviations (SD) and the number of study participants (n) in the individual subgroups.

\begin{tabular}{|c|c|c|c|}
\hline Characteristics & Subgroups & $25(\mathrm{OH}) \mathrm{D}(\mathrm{SD})$ & $\mathbf{N}$ \\
\hline Patient population & & $17.2(7.5)$ & 984 \\
\hline \multirow[t]{3}{*}{ Time of blood sampling } & October - December & $19.4(7.7)$ & 371 \\
\hline & January - March & $15.5(6.9)$ & 384 \\
\hline & April - June & $16.6(7.1)$ & 229 \\
\hline \multirow[t]{2}{*}{ Intake of vitamin D preparations } & no & $16.5(7.1)$ & 838 \\
\hline & yes & $23.3(7.7)$ & 87 \\
\hline \multirow[t]{4}{*}{ BMI } & underweight & $15.9(7.9)$ & 16 \\
\hline & normal weight & $18.0(7.8)$ & 602 \\
\hline & pre-obesity & $16.3(6.4)$ & 261 \\
\hline & obese & $14.8(7.1)$ & 105 \\
\hline \multirow[t]{3}{*}{ Sports activity } & rarely & $15.2(7.0)$ & 271 \\
\hline & sometimes & $16.7(7.4)$ & 329 \\
\hline & often & $19.1(7.5)$ & 384 \\
\hline \multirow[t]{3}{*}{ Time spent outdoors } & rarely & $14.7(6.7)$ & 347 \\
\hline & sometimes & $17.7(7.4)$ & 405 \\
\hline & often & $20.1(7.5)$ & 232 \\
\hline \multirow[t]{2}{*}{ Histological investigation } & no & $17.4(7.5)$ & 882 \\
\hline & yes & 15.7 (6.8) & 102 \\
\hline
\end{tabular}

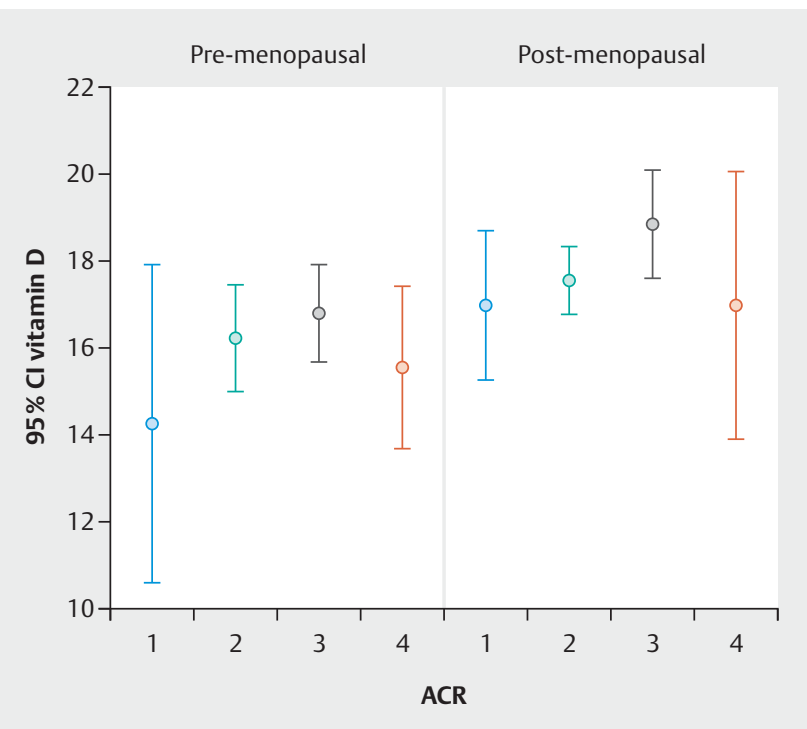

- Fig. 1 Association between vitamin D levels and breast density in pre- and post-menopausal women. Median vitamin D levels and $95 \%$ confidence intervals for the respective ACR categories differentiated according to the menopausal status of the 984 study participants ( $n=412$ pre-menopausal, $n=572$ post-menopausal). Of the pre-menopausal participants $2.9 \%$ had ACR $1,33.0 \%$ had ACR 2 , $46.4 \%$ had ACR 3 and $17.7 \%$ had ACR 4 . Of the post-menopausal women $12.4 \%$ had ACR $1,57.2 \%$ had ACR 2, 26.6\% had ACR 3 and $3.8 \%$ had ACR 4. a physiologically adequate 25 -hydroxyvitamin D supply of at least $30 \mathrm{ng} / \mathrm{ml}$. The lowest mean vitamin D levels were measured in March and the highest were measured in November $(14.65 \mathrm{ng} /$ $\mathrm{ml} \pm 6.61 \mathrm{SD}$ vs. $20.78 \mathrm{ng} / \mathrm{ml} \pm 9.17 \mathrm{SD})$. As expected, women who took daily vitamin $\mathrm{D}$ preparations had higher vitamin $\mathrm{D}$ serum levels than women who took no supplements $(23.29 \mathrm{ng} / \mathrm{ml}$ $\pm 7.66 \mathrm{SD}$ vs. $16.53 \mathrm{ng} / \mathrm{ml} \pm 7.14 \mathrm{SD}$ ). There was an inverse $U$ shaped association between 25(OH)D and BMI, whereby women of normal weight had the highest vitamin D serum levels; the difference between patients of normal weight and obese patients was highly significant $(18.04 \mathrm{ng} / \mathrm{ml} \pm 7.79 \mathrm{SD}$ vs. $14.81 \mathrm{ng} / \mathrm{ml}$ $\pm 7.12 \mathrm{SD} ; \mathrm{t}=4.23, \mathrm{p}<0.001)$. The amount of sports and the time spent outdoors showed an almost linear correlation with 25 $(\mathrm{OH}) \mathrm{D}$. Women who underwent histological work-up following their mammogram $(n=102)$ had average vitamin $D$ levels which were $1.6 \mathrm{ng} / \mathrm{ml}$ lower than women who did not have a biopsy $(15.67 \mathrm{ng} / \mathrm{ml} \pm 6.81 \mathrm{SD}$ vs. $17.37 \mathrm{ng} / \mathrm{ml} \pm 7.51 \mathrm{SD} ; \mathrm{t}=2.37$, $\mathrm{p}=0.019)$. However, the histological findings did not correlate with 25(OH)D levels (cf. - Table 1).

\section{Mammographic breast density (ACR classification)}

The majority of the patient population had an intermediate breast density (ACR 2: $n=463$; ACR 3: $n=343$ ). The percentage of women with high breast density declined significantly following menopause; as the number of years since menopause increased, the percentage of women with a lower breast density increased.

An inverse correlation was also found between ACR and BMI: while every third underweight woman had a very high breast density (ACR 4), none of the obese women had a breast density clas- 
sified as ACR 4. High breast densities (ACR 3 or 4) were found significantly more often in pre-menopausal women for whom biopsy was indicated compared to women who did not require histological work-up (80.9 vs. 61.9\%). Participants with very high breast density tended to have lower $25(\mathrm{OH}) \mathrm{D}$ levels than participants with an average breast density (ACR 4: $15.91 \mathrm{ng} / \mathrm{ml} \pm 7.84 \mathrm{SD}$; ACR 3: $17.74 \mathrm{ng} / \mathrm{ml} \pm 7.77 \mathrm{SD} ; \mathrm{t}=2.03, \mathrm{p}=0.044)$. But after further subdivision according to menopausal status, this difference was no longer significant ( $\triangleright$ Fig. 1). Regular intake of vitamin D supplements suggested a reduction in breast density (cf. • Table 2).

Overall, a total of 386 women - of whom $94 \%$ were post-menopausal at the time of being interviewed by questionnaire - reported having previously taken hormones as part of hormone replacement therapy during menopause. At the time of participating in the study only 111 women were taking hormones. Current hormone intake was not found to be correlated with breast density in this patient subgroup, possibly because breast density decreased significantly with time since menopause.
Both previous hormone therapy and ongoing hormone therapy at the time of the study were associated with higher vitamin D levels compared to women who had never had hormone therapy. The difference in serum levels for women receiving hormone therapy at the time of the study was significantly lower compared to levels for women not currently receiving hormone therapy (difference $0.71 \mathrm{ng} / \mathrm{ml}$ ) and was associated with a significantly bigger error bar than for women with previous hormone treatment compared to women with no previous hormone intake (difference $1.64 \mathrm{ng} / \mathrm{ml})$.

\section{Multivariate logistic model}

A multivariate logistic model with ACR as the dependent variable was used to calculate the impact of the possible main confounders "BMI", "age", "menopausal status" and "25(OH)D" on mammographic breast density (Model 1 in $>$ Table 3). With increasing age and BMI, low breast density was found significantly more often than high breast density (ACR 1 vs. ACR 4, $p<0.001$, respectively). A regression coefficient $B$ of 0.555 for $B M I$ means that it is

- Table 2 Distribution of mammographic breast density (ACR classification) according to menopausal status, years since menopause, BMI class for the pre- und post-menopausal groups and overall; the quantiles of vitamin D levels in the pre- and post-menopausal groups and overall; exogenous vitamin D intake; and according to the indication for biopsy based on mammographic findings. The table shows the percentage of participants in the respective breast density category (from ACR 1 [low density] to 4 [high density]) in the individual subgroups and the absolute sample size of the respective subgroup $(\mathrm{n})$.

\begin{tabular}{|c|c|c|c|c|c|c|c|}
\hline Characteristics & Menopausal status & Subgroups & ACR 1 & ACR 2 & ACR 3 & ACR 4 & $\mathbf{n}$ \\
\hline \multirow[t]{3}{*}{ Patient population } & pre-menopausal & & $2.9 \%$ & $33.0 \%$ & $46.4 \%$ & $17.7 \%$ & 412 \\
\hline & post-menopausal & & $12.4 \%$ & $57.2 \%$ & $26.6 \%$ & $3.8 \%$ & 572 \\
\hline & total & & $8.4 \%$ & $47.1 \%$ & $34.9 \%$ & $9.7 \%$ & 984 \\
\hline \multirow[t]{5}{*}{ Years since menopause } & & $\leq 5$ & $9.9 \%$ & $49.1 \%$ & $31.7 \%$ & $9.3 \%$ & 161 \\
\hline & & $6-10$ & $10.7 \%$ & $57.9 \%$ & $28.9 \%$ & $2.5 \%$ & 121 \\
\hline & & $11-15$ & $14.5 \%$ & $62.7 \%$ & $20.9 \%$ & $1.8 \%$ & 110 \\
\hline & & $16-20$ & $14.5 \%$ & $56.6 \%$ & $27.7 \%$ & $1.2 \%$ & 83 \\
\hline & & $>20$ & $14.4 \%$ & $63.9 \%$ & $20.6 \%$ & $1.0 \%$ & 97 \\
\hline \multirow[t]{12}{*}{ BMI } & pre-menopausal & underweight & & $10.0 \%$ & $40.0 \%$ & $50.0 \%$ & 10 \\
\hline & & normal weight & $0.3 \%$ & $25.4 \%$ & $51.5 \%$ & $22.7 \%$ & 295 \\
\hline & & pre-obese & $2.9 \%$ & $49.3 \%$ & $46.4 \%$ & $1.4 \%$ & 69 \\
\hline & & obese & $23.7 \%$ & $68.4 \%$ & $7.9 \%$ & & 38 \\
\hline & post-menopausal & underweight & & $33.3 \%$ & $66.7 \%$ & & 6 \\
\hline & & normal weight & $6.2 \%$ & $52.8 \%$ & $34.9 \%$ & $6.2 \%$ & 307 \\
\hline & & pre-obese & $16.7 \%$ & $62.5 \%$ & $19.3 \%$ & $1.6 \%$ & 192 \\
\hline & & obese & $29.9 \%$ & $64.2 \%$ & $6.0 \%$ & & 67 \\
\hline & total & underweight & & $18.8 \%$ & $50.0 \%$ & $31.3 \%$ & 16 \\
\hline & & normal weight & $3.3 \%$ & $39.4 \%$ & $43.0 \%$ & $14.3 \%$ & 602 \\
\hline & & pre-obese & $13.0 \%$ & $59.0 \%$ & $26.4 \%$ & $1.5 \%$ & 261 \\
\hline & & obese & $27.6 \%$ & $65.7 \%$ & $6.7 \%$ & & 105 \\
\hline \multirow[t]{5}{*}{ 25(OH)D level } & pre-menopausal & $<5$ & & $33.3 \%$ & $50.0 \%$ & $16.7 \%$ & 6 \\
\hline & & $5-9$ & $2.7 \%$ & $37.0 \%$ & $43.8 \%$ & $16.4 \%$ & 73 \\
\hline & & $10-19$ & $3.8 \%$ & $30.7 \%$ & $44.3 \%$ & $21.2 \%$ & 212 \\
\hline & & $20-29$ & $2.0 \%$ & $36.0 \%$ & $51.0 \%$ & $11.0 \%$ & 100 \\
\hline & & $\geq 30$ & & $28.6 \%$ & $52.4 \%$ & $19.0 \%$ & 21 \\
\hline
\end{tabular}


- Table 2 Distribution of mammographic breast density (ACR classification) according to menopausal status, years since menopause, BMI class for the pre- und post-menopausal groups and overall; the quantiles of vitamin D levels in the pre- and post-menopausal groups and overall; exogenous vitamin D intake; and according to the indication for biopsy based on mammographic findings. The table shows the percentage of participants in the respective breast density category (from ACR 1 [low density] to 4 [high density]) in the individual subgroups and the absolute sample size of the respective subgroup (n). (Continued)

\begin{tabular}{|c|c|c|c|c|c|c|c|}
\hline \multirow[t]{11}{*}{ Characteristics } & Menopausal status & Subgroups & ACR 1 & ACR 2 & ACR 3 & ACR 4 & n \\
\hline & post-menopausal & $<5$ & & $66.7 \%$ & $33.3 \%$ & & 6 \\
\hline & & $5-9$ & $16.4 \%$ & $52.7 \%$ & $29.1 \%$ & $1.8 \%$ & 55 \\
\hline & & $10-19$ & $12.7 \%$ & $59.7 \%$ & $23.0 \%$ & $4.7 \%$ & 300 \\
\hline & & $20-29$ & $11.4 \%$ & $55.4 \%$ & $30.3 \%$ & $2.9 \%$ & 175 \\
\hline & & $\geq 30$ & $11.1 \%$ & $50.0 \%$ & $33.3 \%$ & $5.6 \%$ & 36 \\
\hline & total & $<5$ & & $50.0 \%$ & $41.7 \%$ & $8.3 \%$ & 12 \\
\hline & & $5-9$ & $8.6 \%$ & $43.8 \%$ & $37.5 \%$ & $10.2 \%$ & 128 \\
\hline & & $10-19$ & $9.0 \%$ & $47.7 \%$ & $31.8 \%$ & $11.5 \%$ & 512 \\
\hline & & $20-29$ & $8.0 \%$ & $48.4 \%$ & $37.8 \%$ & $5.8 \%$ & 275 \\
\hline & & $\geq 30$ & $7.0 \%$ & $42.1 \%$ & $40.4 \%$ & $10.5 \%$ & 57 \\
\hline \multirow[t]{6}{*}{ Vitamin D preparations } & pre-menopausal & no & $2.8 \%$ & $32.2 \%$ & $46.2 \%$ & $18.8 \%$ & 388 \\
\hline & & yes & $9.2 \%$ & $45.5 \%$ & $45.5 \%$ & & 11 \\
\hline & post-menopausal & no & $13.1 \%$ & $58.4 \%$ & $23.8 \%$ & $4.7 \%$ & 450 \\
\hline & & yes & $11.8 \%$ & $47.4 \%$ & $39.5 \%$ & $1.3 \%$ & 76 \\
\hline & total & no & $8.4 \%$ & $46.3 \%$ & $34.1 \%$ & $11.2 \%$ & 838 \\
\hline & & yes & $11.5 \%$ & $47.1 \%$ & $40.2 \%$ & $1.1 \%$ & 87 \\
\hline \multirow[t]{6}{*}{ Biopsy } & pre-menopausal & no & $3.3 \%$ & $34.8 \%$ & $43.8 \%$ & $18.1 \%$ & 365 \\
\hline & & yes & & $19.1 \%$ & $66.0 \%$ & $14.9 \%$ & 47 \\
\hline & post-menopausal & no & $12.8 \%$ & $56.9 \%$ & $26.1 \%$ & $4.3 \%$ & 517 \\
\hline & & yes & $9.1 \%$ & $60.0 \%$ & $30.9 \%$ & & 55 \\
\hline & total & no & $8.8 \%$ & $47.7 \%$ & $33.4 \%$ & $10.0 \%$ & 882 \\
\hline & & yes & $4.9 \%$ & $41.2 \%$ & $47.1 \%$ & $6.9 \%$ & 102 \\
\hline
\end{tabular}

e0.555 $=1.742$ times more probable that a woman will have a very low breast density (ACR 1) rather than a high breast density (ACR 4) when BMl is increased by one unit. Post-menopausal women had a greater probability of having a very low breast density (ACR 1) compared to pre-menopausal women ( $B=1.203$ for $p=0.044)$. Higher vitamin $D$ levels were more likely in women with medium breast density (ACR 2 and 3) compared to women with high breast density $(p=0.032$ and $p=0.028)$. The respective regression coefficients of $25(\mathrm{OH}) \mathrm{D}$ were approximately the same for $A C R$ groups 1 to $3(B=0.042 ; 0.038 ; 0.037)$. There were only slight differences in vitamin $D$ levels between these 3 categories, but all 3 categories had higher vitamin D levels compared to the high breast density group ( $\vee$ Table 3 ).

After separately analyzing pre- and post-menopausal women, post-menopausal BMI and age were found to be inversely correlated with breast density ( $p<0.001)$. 25-Hydroxyvitamin D did not appear to have an effect on post-menopausal breast density. This was in contrast to the findings for pre-menopausal test subjects where BMI was negatively associated with breast density $(p<0.001)$, but not age. Higher vitamin D levels were not found significantly more often in women with medium breast density (ACR 2) compared to women with ACR $4(p=0.060)$, possibly due to the smaller size of this group $(n=412)$.
After adjusting for all recorded breast changes and for familial risk for breast and ovarian cancer according to Meindl's findings [29], BI-RADS 1 or 2 was unsurprisingly found to be associated significantly more often with ACR 1 than BI-RADS categories 5 or 6 $(p<0.001)$.

Of all the other gynecological parameters studied, only a history of bilateral ovariectomy was found to be associated with significantly lower breast density (ACR 1: $B=18.55, A C R 2$ : $B=18.52$ with $\mathrm{p}<0.001$, respectively).

\section{Effect of exogenous vitamin D intake}

When the eating habits of the test subjects were included in the analysis, the daily intake of vitamin D preparations in the overall patient population was only weakly associated with lower breast density (ACR 3: $B=2.41, p=0.05$ ). But if pre- and post-menopausal women were analyzed separately, pre-menopausal women with regular intake of vitamin D preparations had a significantly lower breast density compared to pre-menopausal women who did not take vitamin D supplements $(p<0.001)$. In pre-menopausal women, age was not correlated with breast density. In postmenopausal women, the intake of vitamin D supplements appeared to have no effect on ACR in contrast to age which appeared to strongly affect breast density. Neither vitamin D-con- 
- Table 3 Regression coefficients for the effect of various influencing factors on mammographic breast density using the ACR (American College of Radiologists) classification and eight different logistic regression models. The table shows the regression coefficients and standard error (in brackets). Model 1: adjusted for the main parameters: BMI (continuous), age (continuous), post-menopause (reference: pre-menopause), 25(OH)D (continuous). Model 2: pre-menopausal patient group: adjusted for BMI (continuous), age (continuous), 25(OH)D (continuous).

Model 3: post-menopausal patient group: adjusted for BMI (continuous), age (continuous), 25(OH)D (continuous).

Model 4: breast parameters: listed independent variables: main parameter, BI-RADS 1/2 (reference: BI-RADS 5/6); independent variables not listed here: BI-RADS 0, BI-RADS 3/4, mastitis, breast surgery, benign breast changes, breast biopsy, familial risk for breast and ovarian cancer.

Model 5: gynecological parameters: independent variables listed: main parameter, bilateral ovariectomy (reference: no ovariectomy); independent variables not listed here: age at menarche, HRT, hysterectomy.

Model 6: eating habits: independent variables listed: main parameter, intake of vitamin D preparations (reference: no intake of vitamin D preparation); independent variables not listed here: intake of fish/milk/yoghurt/cheese, intake of Ca preparations.

Model 7: pre-menopausal cohort: confounders the same as in Model 6 with the exception of post-menopause.

Model 8: post-menopausal cohort: confounders the same as in Model 6 with the exception of post-menopause.

\begin{tabular}{|c|c|c|c|c|c|c|c|c|c|}
\hline \multirow[t]{2}{*}{ Confounder } & \multirow[t]{2}{*}{$\mathrm{ACR}^{\mathrm{a}}$} & \multicolumn{8}{|l|}{ Models } \\
\hline & & Model 1 & Model 2 & Model 3 & Model 4 & Model 5 & Model 6 & Model 7 & Model 8 \\
\hline \multirow[t]{3}{*}{ Constant term } & 1 & $\begin{array}{l}-21.037^{* * *} \\
(1.773)\end{array}$ & $\begin{array}{l}-24.574^{* * *} \\
(4.846)\end{array}$ & $\begin{array}{l}-18.645^{* * *} \\
(3.053)\end{array}$ & $\begin{array}{l}-41.642^{* * *} \\
(2.136)\end{array}$ & $\begin{array}{l}-20.434^{* * *} \\
(1.927)\end{array}$ & $\begin{array}{l}-21.030^{* * *} \\
(2.231)\end{array}$ & $\begin{array}{l}-28.870^{* * *} \\
(7.300)\end{array}$ & $\begin{array}{l}-20.146^{* * *} \\
(3.601)\end{array}$ \\
\hline & 2 & $\begin{array}{l}-13.064^{* * *} \\
(1.357)\end{array}$ & $\begin{array}{l}-11.824^{* * *} \\
(1.945)\end{array}$ & $\begin{array}{l}-12.521^{* * *} \\
(2.736)\end{array}$ & $\begin{array}{l}-12.302^{* * *} \\
(1.842)\end{array}$ & $\begin{array}{l}-12.650^{* * *} \\
(1.491)\end{array}$ & $\begin{array}{l}-12.504^{* * *} \\
(1.730)\end{array}$ & $\begin{array}{l}-12.422^{* * *} \\
(2.368)\end{array}$ & $\begin{array}{l}-13.172^{* * *} \\
(3.224)\end{array}$ \\
\hline & 3 & $\begin{array}{l}-6.518^{* * *} \\
(1.274)\end{array}$ & $\begin{array}{l}-5.757^{* * *} \\
(1.720)\end{array}$ & $\begin{array}{l}-7.912^{* *} \\
(2.738)\end{array}$ & $\begin{array}{l}-6.301^{* * *} \\
(1.741)\end{array}$ & $\begin{array}{l}-6.499^{* * *} \\
(1.405)\end{array}$ & $\begin{array}{l}-6.291^{* * *} \\
(1.655)\end{array}$ & $\begin{array}{l}-5.727^{* *} \\
(2.106)\end{array}$ & $\begin{array}{l}-7.532^{*} \\
(3.226)\end{array}$ \\
\hline \multirow[t]{3}{*}{ BMI } & 1 & $\begin{array}{l}0.555^{* * *} \\
(0.059)\end{array}$ & $\begin{array}{l}0.753^{* * *} \\
(0.101)\end{array}$ & $\begin{array}{l}0.426^{* * *} \\
(0.092)\end{array}$ & $\begin{array}{l}0.596^{* * *} \\
(0.062)\end{array}$ & $\begin{array}{l}0.555^{* * *} \\
(0.060)\end{array}$ & $\begin{array}{l}0.557^{* * *} \\
(0.068)\end{array}$ & $\begin{array}{l}0.808^{* * *} \\
(0.133)\end{array}$ & $\begin{array}{l}0.459^{* * *} \\
(0.101)\end{array}$ \\
\hline & 2 & $\begin{array}{l}0.421^{* * *} \\
(0.054)\end{array}$ & $\begin{array}{l}0.505^{* * *} \\
(0.072)\end{array}$ & $\begin{array}{l}0.316^{* * *} \\
(0.088)\end{array}$ & $\begin{array}{l}0.431^{* * *} \\
(0.055)\end{array}$ & $\begin{array}{l}0.425^{* * *} \\
(0.054)\end{array}$ & $\begin{array}{l}0.421^{* * *} \\
(0.061)\end{array}$ & $\begin{array}{l}0.509^{* * *} \\
(0.084)\end{array}$ & $\begin{array}{l}0.330^{* * *} \\
(0.096)\end{array}$ \\
\hline & 3 & $\begin{array}{l}0.227^{* * *} \\
(0.052)\end{array}$ & $\begin{array}{l}0.271^{* * *} \\
(0.067)\end{array}$ & $\begin{array}{l}0.149 \\
(0.089)\end{array}$ & $\begin{array}{l}0.231^{* * *} \\
(0.054)\end{array}$ & $\begin{array}{l}0.228^{* * *} \\
(0.053)\end{array}$ & $\begin{array}{l}0.219^{* * *} \\
(0.060)\end{array}$ & $\begin{array}{l}0.266^{* * *} \\
(0.079)\end{array}$ & $\begin{array}{l}0.142 \\
(0.098)\end{array}$ \\
\hline \multirow[t]{3}{*}{ Age } & 1 & $\begin{array}{l}0.092^{* * *} \\
(0.025)\end{array}$ & $\begin{array}{l}0.068 \\
(0.074)\end{array}$ & $\begin{array}{l}0.145^{* * *} \\
(0.035)\end{array}$ & $\begin{array}{l}0.110^{* * *} \\
(0.027)\end{array}$ & $\begin{array}{l}0.097^{* * *} \\
(0.026)\end{array}$ & $\begin{array}{l}0.090^{* * *} \\
(0.028)\end{array}$ & $\begin{array}{l}0.110 \\
(0.099)\end{array}$ & $\begin{array}{l}0.137^{* * *} \\
(0.039)\end{array}$ \\
\hline & 2 & $\begin{array}{l}0.063^{* *} \\
(0.020)\end{array}$ & $\begin{array}{l}0.007 \\
(0.030)\end{array}$ & $\begin{array}{l}0.120^{* * *} \\
(0.032)\end{array}$ & $\begin{array}{l}0.071^{* * *} \\
(0.021)\end{array}$ & $\begin{array}{l}0.066^{* *} \\
(0.021)\end{array}$ & $\begin{array}{l}0.060^{* *} \\
(0.023)\end{array}$ & $\begin{array}{l}-0.006 \\
(0.035)\end{array}$ & $\begin{array}{l}0.114^{* * *} \\
(0.036)\end{array}$ \\
\hline & 3 & $\begin{array}{l}0.043^{*} \\
(0.019)\end{array}$ & $\begin{array}{l}0.007 \\
(0.027)\end{array}$ & $\begin{array}{l}0.097^{* *} \\
(0.032)\end{array}$ & $\begin{array}{l}0.050^{*} \\
(0.021)\end{array}$ & $\begin{array}{l}0.045^{*} \\
(0.021)\end{array}$ & $\begin{array}{l}0.035 \\
(0.022)\end{array}$ & $\begin{array}{l}-0.002 \\
(0.032)\end{array}$ & $\begin{array}{l}0.085^{*} \\
(0.036)\end{array}$ \\
\hline \multirow[t]{3}{*}{ Post-menopause } & 1 & $\begin{array}{l}1.203^{*} \\
(0.597)\end{array}$ & & & $\begin{array}{l}1.020 \\
(0.615)\end{array}$ & $\begin{array}{l}1.272^{*} \\
(0.633)\end{array}$ & $\begin{array}{l}0.992 \\
(0.675)\end{array}$ & & \\
\hline & 2 & $\begin{array}{l}0.745 \\
(0.421)\end{array}$ & & & $\begin{array}{l}0.676 \\
(0.425)\end{array}$ & $\begin{array}{l}0.570 \\
(0.458)\end{array}$ & $\begin{array}{l}0.378 \\
(0.476)\end{array}$ & & \\
\hline & 3 & $\begin{array}{l}0.068 \\
(0.411)\end{array}$ & & & $\begin{array}{l}0.013 \\
(0.415)\end{array}$ & $\begin{array}{l}0.003 \\
(0.448)\end{array}$ & $\begin{array}{l}-0.029 \\
(0.470)\end{array}$ & & \\
\hline \multirow[t]{3}{*}{ 25(OH)D } & 1 & $\begin{array}{l}0.042 \\
(0.024)\end{array}$ & $\begin{array}{l}0.071 \\
(0.053)\end{array}$ & $\begin{array}{l}0.045 \\
(0.037)\end{array}$ & $\begin{array}{l}0.044 \\
(0.025)\end{array}$ & $\begin{array}{l}0.043 \\
(0.024)\end{array}$ & $\begin{array}{l}0.072^{*} \\
(0.029)\end{array}$ & $\begin{array}{l}0.097 \\
(0.076)\end{array}$ & $\begin{array}{l}0.055 \\
(0.044)\end{array}$ \\
\hline & 2 & $\begin{array}{l}0.038^{*} \\
(0.018)\end{array}$ & $\begin{array}{l}0.041 \\
(0.022)\end{array}$ & $\begin{array}{l}0.041 \\
(0.033)\end{array}$ & $\begin{array}{l}0.038^{*} \\
(0.018)\end{array}$ & $\begin{array}{l}0.038^{*} \\
(0.018)\end{array}$ & $\begin{array}{l}0.065^{* *} \\
(0.022)\end{array}$ & $\begin{array}{l}0.073^{* *} \\
(0.028)\end{array}$ & $\begin{array}{l}0.049 \\
(0.040)\end{array}$ \\
\hline & 3 & $\begin{array}{l}0.037^{*} \\
(0.017)\end{array}$ & $\begin{array}{l}0.031 \\
(0.020)\end{array}$ & $\begin{array}{l}0.048 \\
(0.033)\end{array}$ & $\begin{array}{l}0.037^{*} \\
(0.017)\end{array}$ & $\begin{array}{l}0.038^{*} \\
(0.017)\end{array}$ & $\begin{array}{l}0.055^{* *} \\
(0.021)\end{array}$ & $\begin{array}{l}0.064^{*} \\
(0.026)\end{array}$ & $\begin{array}{l}0.031 \\
(0.040)\end{array}$ \\
\hline \multirow[t]{3}{*}{ BI-RADS $1 / 2$} & 1 & & & & $\begin{array}{l}20.486^{* * *} \\
(0.731)\end{array}$ & & & & \\
\hline & 2 & & & & $\begin{array}{l}-0.518 \\
(1.032)\end{array}$ & & & & \\
\hline & 3 & & & & $\begin{array}{l}-0.565 \\
(0.972)\end{array}$ & & & & \\
\hline \multirow[t]{3}{*}{$\begin{array}{l}\text { Bilateral } \\
\text { ovariectomy }\end{array}$} & 1 & & & & & $\begin{array}{l}18.546^{* * *} \\
(0.598)\end{array}$ & & & \\
\hline & 2 & & & & & $\begin{array}{l}18.524^{* * *} \\
(0.368) \\
-\end{array}$ & & & \\
\hline & 3 & & & & & & & & \\
\hline
\end{tabular}


- Table 3 Regression coefficients for the effect of various influencing factors on mammographic breast density using the ACR (American College of Radiologists) classification and eight different logistic regression models. The table shows the regression coefficients and standard error (in brackets). Model 1: adjusted for the main parameters: BMI (continuous), age (continuous), post-menopause (reference: pre-menopause), 25(OH)D (continuous). Model 2: pre-menopausal patient group: adjusted for BMI (continuous), age (continuous), 25(OH)D (continuous).

Model 3: post-menopausal patient group: adjusted for BMI (continuous), age (continuous), 25(OH)D (continuous).

Model 4: breast parameters: listed independent variables: main parameter, BI-RADS 1/2 (reference: BI-RADS 5/6); independent variables not listed here: BI-RADS 0, BI-RADS 3/4, mastitis, breast surgery, benign breast changes, breast biopsy, familial risk for breast and ovarian cancer.

Model 5: gynecological parameters: independent variables listed: main parameter, bilateral ovariectomy (reference: no ovariectomy); independent variables not listed here: age at menarche, HRT, hysterectomy.

Model 6: eating habits: independent variables listed: main parameter, intake of vitamin D preparations (reference: no intake of vitamin D preparation); independent variables not listed here: intake of fish/milk/yoghurt/cheese, intake of Ca preparations.

Model 7: pre-menopausal cohort: confounders the same as in Model 6 with the exception of post-menopause.

Model 8: post-menopausal cohort: confounders the same as in Model 6 with the exception of post-menopause. (Continued)

\begin{tabular}{|c|c|c|c|c|c|c|c|c|c|}
\hline \multirow[t]{2}{*}{ Confounder } & \multirow[t]{2}{*}{$\mathrm{ACR}^{\mathrm{a}}$} & \multicolumn{8}{|l|}{ Models } \\
\hline & & Model 1 & Model 2 & Model 3 & Model 4 & Model 5 & Model 6 & Model 7 & Model 8 \\
\hline \multirow[t]{3}{*}{$\begin{array}{l}\text { Intake of vitamin D } \\
\text { preparations }\end{array}$} & 1 & & & & & & $\begin{array}{l}1.533 \\
(1.344)\end{array}$ & $\begin{array}{l}20.265^{* * *} \\
(3.539)\end{array}$ & $\begin{array}{l}0.737 \\
(1.543)\end{array}$ \\
\hline & 2 & & & & & & $\begin{array}{l}1.684 \\
(1.221)\end{array}$ & $\begin{array}{l}20.096^{* * *} \\
(0.942)\end{array}$ & $\begin{array}{l}0.974 \\
(1.435)\end{array}$ \\
\hline & 3 & & & & & & $\begin{array}{l}2.407^{*} \\
(1.229)\end{array}$ & - & $\begin{array}{l}1.892 \\
(1.467)\end{array}$ \\
\hline
\end{tabular}

a: ACR 4 was used as the reference category.

${ }^{* * *},{ }^{* *},{ }^{*}$ : statistically the regression coefficient does not equal zero at a significance level of 0.1 or 1 or $5 \%$.

taining nutrition, blood parameters (calcium, phosphate, creatinine), sports, the use of sun screen and the amount of time spent outside nor alcohol and smoking and the number of pregnancies and age at pregnancy were found to be unambiguously associated with breast density. When the figures were controlled for vitamin $D$-containing nutrition including the intake of vitamin $D$ supplements, the negative association between $25(\mathrm{OH}) \mathrm{D}$ and ACR was heightened. The results of all other regression models on the association between vitamin $\mathrm{D}$ and breast density were very similar to those of Model 1.

\section{Discussion}

25(OH)D levels of less than $10 \mathrm{ng} / \mathrm{ml}$ are considered deficient [30, 31]. Since 2010 many countries have raised the previous minimum value for normal vitamin D levels from 20 to $30 \mathrm{ng} / \mathrm{ml}$. It is not yet clear to what extent this could have an impact on cancer prevention or other pleiotropic effects of vitamin D [30].

In our study only $6 \%$ of participants had sufficient vitamin $D$ supply ( $\geq 30 \mathrm{ng} / \mathrm{ml}$ ), and just under two thirds had low vitamin D levels $(<20 \mathrm{ng} / \mathrm{ml})$. Although vitamin D deficits were far more common in our patient population compared to the percentages described in other European studies, those studies often differed strongly from our study in their choice of patient population or study criteria [32-35].

As cutaneous vitamin D synthesis depends very much on the incidence angle of the sun's rays [36], the seasonal fluctuations of vitamin D levels found in our study population are unsurprising, with the lowest levels recorded in March (mean: $14.65 \mathrm{ng} / \mathrm{ml}$ ) and the highest levels found in October and November (20.36 and
$20.78 \mathrm{ng} / \mathrm{ml})$. The quantitative time spent outside was highly positively correlated with $25(\mathrm{OH}) \mathrm{D}$ levels, while the intake of vitamin D-rich food was not at all correlated with $25(\mathrm{OH}) \mathrm{D}$ levels. In people below the age of 60 years, cutaneous synthesis is the main supplier of vitamin D with a share of up to $90 \%$; food plays a subordinate role for vitamin $\mathrm{D}$ balance $[37,38]$. This appears to be different in countries in which nutrition such as dairy products and cereals are fortified with vitamin D. A systematic review by O'Donnell et al. [39] reported a significantly positive impact on vitamin D levels of products with vitamin D supplements. In our study population, regular intake of vitamin $D$ preparations was associated with a mean elevation of vitamin D serum levels by $40 \%$.

Frequent sports activities were also found to correlate positively with vitamin D levels, as sports are often played outdoors $[40,41]$ and there is a negative correlation between sports and BMI $[42,43]$. BMI is also being discussed as an influencing factor for $25(\mathrm{OH}) \mathrm{D}$ levels as both severely underweight and obese women expose less skin to the sun and are more likely to avoid outdoor activities $[44,45]$. The results of our study also appear to indicate an inverse association between BMI and vitamin D. Adipose tissue stores vitamin D and can therefore deplete the amount of 25 $(\mathrm{OH}) \mathrm{D}$ present in blood, contributing to decreased serum levels of vitamin D [46]. Possible genetic connections are also being discussed. A recent study by Vimaleswaran et al., which included 42024 participants, showed that vitamin D deficiency occurred more commonly in people with obesity-specific genetic variants [47].

Our analyses showed an inverse association between BMI and breast density. In addition to breast density, BMI is also counted as one of the most important risk factors for post-menopausal breast cancer [48]. Adipose tissue, which produces estrogens 
through aromatization, promotes cell proliferation and mutations and increases both breast density and the risk of breast cancer $[49,50]$. In women with higher BMI the total percentage of body fat as well as the percentage of breast fat is elevated, which also explains the inverse association between BMI and breast density $[51,52]$.

The post-menopausal reduction of mammographic density, which was also found in our data, can be explained by the decreasing number of epithelial and stromal cells following menopause $[53,54]$. Unsurprisingly therefore, bilateral ovariectomy was found to be highly significantly associated with lower breast density. The association between breast density and risk for breast cancer could also be genetic [55-57].

\section{Association between vitamin $\mathrm{D}$ and breast density}

In our analysis, regular intake of vitamin D preparations was associated slightly more (just reaching significance) with intermediate breast density (ACR 3) than with high breast density (ACR 4) ( $p=0.05$; Table 3: Model 6). The intake of vitamin D-rich food did not appear to be relevant for breast density. Other studies which examined a possible association between vitamin D and breast density generally only looked at the intake of vitamin $D$ from nutrition using specific questionnaires but did not look at vitamin $D$ levels in serum. In post-menopausal women there was usually no correlation $[23,24,58-60]$, while the breast density of pre-menopausal women appeared to be significantly inversely associated with vitamin D intake $[22,58,59,61]$. But as these studies used percentage breast tissue density instead of the ACR classification used in our study, only limited comparisons are possible. As far as the authors of this study could determine, only one other study has also used the ACR classification to determine breast density [25]. That study reported a marginally significant inverse relation between ACR and vitamin D intake in women with a high familial risk of breast and ovarian cancer. In our study population, pre-menopausal women who took regular vitamin D supplements were more likely to have low breast densities and this likelihood was highly significant, but with a relatively large regression coefficient (>20) compared to pre-menopausal women with no vitamin $D$ intake, although the sample size of this evaluation was considerably smaller than that used in Model 6. No such association was found for post-menopausal women.

Whether the intake of vitamin D preparations could lead to a reduction in breast density at least in pre-menopausal women is therefore still not clear.

Our findings indicate a conditional inverse connection between 25(OH)D and breast density. Although following multivariate adjustment the presence of low vitamin levels made the probability of high breast density (ACR 4) significantly more likely, vitamin $D$ serum levels for the respective ACR groups $1-3$ barely differed from one another. It could therefore be assumed that vitamin $D$ levels are only important in women with high breast density. The few studies on the effect of vitamin D on mammographic density mainly examined post-menopausal participants and found almost no associations [26,62-64]. The recently published analysis by Bertrand et al. of 835 pre-menopausal women showed significantly higher percent breast tissue densities for women with vitamin D levels in the highest $25(\mathrm{OH}) \mathrm{D}$ quartile compared to levels in the lowest 25(OH)D quartile [27]. After including the respective risk for breast cancer, they found that higher vitamin $D$ serum levels in women with high breast density were correlated with a lower risk for breast cancer. No such association was found for women with low to medium breast density. This is in accordance with our findings.

When separate regression analyses were done for pre- and post-menopausal women, the results differed strongly from those of Model 1; while BMI and ACR correlated inversely in both premenopausal and post-menopausal women and this inverse correlation was highly significant, age was inversely associated with breast density only in post-menopausal women. In pre-menopausal participants, higher vitamin D serum levels tended to be associated with lower breast density ( $p=0.060$ for ACR 2 vs. ACR 4); no such association was found in post-menopausal women. The results therefore indicate that the effect of vitamin $D$ serum levels is primarily pre-menopausal. After menopause, $25(\mathrm{OH}) \mathrm{D}$ appears to play a subordinate role for breast density. Because breast density significantly decreases as the time since menopause increases, no significant effect of current hormone therapy on breast density was found in the small study population receiving HT $(n=111)$.

\section{Conclusion}

Although a strong antiproliferative and immunomodulatory effect is ascribed to vitamin $\mathrm{D}$, up to now the findings of studies on possible connections between vitamin $\mathrm{D}$ and breast cancer have been very heterogeneous. The possible association with breast density as an established risk factor for breast cancer is still controversially discussed.

The results of our large cross-sectional study with just under 1000 participants indicate an inverse relationship between vitamin D and mammographic density which appears to be strongly dependent on menopausal status. Even after multivariate adjustment for different factors influencing breast density, the incidence of low breast density was significantly higher for all premenopausal women who had either high 25(OH)D levels or who took regular vitamin D supplements ( $\vee$ Table 3, Models 2 and 7 ). After menopause, vitamin D was not correlated with ACR; BMI and age however were significantly correlated inversely with breast density.

More studies will be necessary to confirm the hypothesis of a primarily pre-menopausal relationship between vitamin $\mathrm{D}$ and breast density. In addition to possible long-term effects of 25(OH)D and vitamin D supplements on breast density, a follow-up study could record the incidence of breast cancer. The results of such studies could possibly bring us one step closer to successfully preventing breast cancer.

Irrespective of how important vitamin D is for the prevention of breast cancer, there is now a broad consensus that vitamin D insufficiency is very common in the general population and should not be underestimated. The well-known and significant negative consequences of this on bone density and the possible connection to a number of other diseases make it all the more important to investigate and understand the precise mechanism of 
action of vitamin $\mathrm{D}$ and its derivatives in the human body in further studies.

\section{Conflict of Interest}

The authors declare that they have no conflict of interest.

\section{References}

[1] Imtiaz S, Siddiqui N, Raza SA et al. Vitamin D deficiency in newly diagnosed breast cancer patients. Indian J Endocrinol Metab 2012; 16: 409413

[2] Khan KA, Akram J, Fazal M. Hormonal actions of vitamin D and its role beyond just being a vitamin: a review article. Int J Med Sci 2011; 3: 6572

[3] Kirchner H, Mühlhäußer J. Basics Biochemie. München: Elsevier $\mathrm{GmbH}$, Urban \& Fischer Verlag; 2009

[4] Holick MF. The vitamin D epidemic and its health consequences. J Nutr 2005; 135: 2739S-2748S

[5] Woitge HW, Scheidt-Nave C, Kissling C et al. Seasonal variation of biochemical indexes of bone turnover: results of a population-based study. J Clin Endocrinol Metab 1998; 83: 68-75

[6] Khan QJ, Kimler BF, Fabian C]. The relationship between vitamin D and breast cancer incidence and natural history. Curr Oncol Rep 2010; 12: 136-142

[7] Giovannucci E. The epidemiology of vitamin $D$ and cancer incidence and mortality: a review (United States). Cancer Causes Control 2005; 16: 8395

[8] Cui Y, Rohan TE. Vitamin D, calcium, and breast cancer risk: a review. Cancer Epidemiol Biomarkers Prev 2006; 15: 1427-1437

[9] Deeb KK, Trump DL, Johnson CS. Vitamin D signalling pathways in cancer: potential for anticancer therapeutics. Nat Rev Cancer 2007; 7: 684700

[10] Lowe LC, Guy M, Mansi JL et al. Plasma 25-hydroxy vitamin D concentrations, vitamin D receptor genotype and breast cancer risk in a UK Caucasian population. Eur J Cancer 2005; 41: 1164-1169

[11] Crew KD, Gammon MD, Steck SE et al. Association between plasma 25hydroxyvitamin D and breast cancer risk. Cancer Prev Res (Phila) 2009; 2: 598-604

[12] Knight JA, Lesosky M, Barnett $\mathrm{H}$ et al. Vitamin $\mathrm{D}$ and reduced risk of breast cancer: a population-based case-control study. Cancer Epidemiol Biomarkers Prev 2007; 16: 422-429

[13] Robien K, Cutler G], Lazovich D. Vitamin D intake and breast cancer risk in postmenopausal women: the lowa Women's Health Study. Cancer Causes Control 2007; 18: 775-782

[14] Colston KW, Lowe LC, Mansi JL et al. Vitamin D status and breast cancer risk. Anticancer Res 2006; 26: 2573-2580

[15] Rossi M, McLaughlin JK, Lagiou P et al. Vitamin D intake and breast cancer risk: a case-control study in Italy. Ann Oncol 2009; 20: 374-378

[16] Imtiaz S, Siddiqui N. Vitamin-D status at breast cancer diagnosis: correlation with social and environmental factors and dietary intake. J Ayub Med Coll Abbottabad 2014; 26: 186-190

[17] Chlebowski RT, Johnson KC, Kooperberg C et al.; Women's Health Initiative Investigators. Calcium plus vitamin $\mathrm{D}$ supplementation and the risk of breast cancer. J Natl Cancer Inst 2008; 100: 1581-1591

[18] Freedman DM, Chang SC, Falk RT et al. Serum levels of vitamin D metabolites and breast cancer risk in the prostate, lung, colorectal, and ovarian cancer screening trial. Cancer Epidemiol Biomarkers Prev 2008; 17: 889894

[19] Lin J, Manson JE, Lee IM et al. Intakes of calcium and vitamin D and breast cancer risk in women. Arch Intern Med 2007; 167: 1050-1059
[20] Chen P, Hu P, Xie D et al. Meta-analysis of vitamin D, calcium and the prevention of breast cancer. Breast Cancer Res Treat 2010; 121: 469477

[21] Boyd NF, Rommens JM, Vogt K et al. Mammographic breast density as an intermediate phenotype for breast cancer. Lancet Oncol 2005; 6: 798808

[22] Bérubé S, Diorio C, Verhoek-Oftedahl W et al. Vitamin D, calcium, and mammographic breast densities. Cancer Epidemiol Biomarkers Prev 2004; 13: 1466-1472

[23] Masala G, Ambrogetti D, Assedi M et al. Dietary and lifestyle determinants of mammographic breast density. A longitudinal study in a Mediterranean population. Int J Cancer 2006; 118: 1782-1789

[24] Mishra G, McCormack V, Kuh D et al. Dietary calcium and vitamin D intakes in childhood and throughout adulthood and mammographic density in a British birth cohort. Br J Cancer 2008; 99: 1539-1543

[25] Tseng M, Byrne C, Evers KA et al. Dietary intake and breast density in high-risk women: a cross-sectional study. Breast Cancer Res 2007; 9: R72

[26] Green AK, Hankinson SE, Bertone-Johnson ER et al. Mammographic density, plasma vitamin $D$ levels and risk of breast cancer in postmenopausal women. Int J Cancer 2010; 127: 667-674

[27] Bertrand KA, Rosner B, Eliassen AH et al. Premenopausal plasma 25-hydroxyvitamin D, mammographic density, and risk of breast cancer. Breast Cancer Res Treat 2015; 149: 479-487

[28] Riedel J, Richter L, Wissing J et al. Vitamin D and mammographic findings. Geburtsh Frauenheilk 2016; 76: 570-578

[29] Meindl A, Ditsch N, Kast K et al. Hereditary breast and ovarian cancer new genes, new treatments, new concepts. Dtsch Arztebl Int 2011; 108 (19): $323-330$

[30] Spiro A, Buttriss JL. Vitamin D: An overview of vitamin D status and intake in Europe. Nutr Bull 2014; 39: 322-350

[31] Bischoff-Ferrari H. Vitamin D: what is an adequate vitamin D level and how much supplementation is necessary? Best Pract Res Clin Rheumatol 2009; 23: 789-795

[32] Burnand B, Sloutskis D, Gianoli F et al. Serum 25-hydroxyvitamin D: distribution and determinants in the Swiss population. Am J Clin Nutr 1992; 56: 537-542

[33] MacFarlane GD, Sackrison JL jr., Body JJ et al. Hypovitaminosis D in a normal, apparently healthy urban European population. J Steroid Biochem Mol Biol 2004; 89-90: 621-622

[34] Meyer C. Scientists probe role of vitamin D: deficiency a significant problem, experts say. JAMA 2004; 292: 1416-1418

[35] Hintzpeter B, Mensink GB, Thierfelder W et al. Vitamin D status and health correlates among German adults. Eur I Clin Nutr 2008; 62 : 1079-1089

[36] Stingl W. 10 Minuten täglich an die Sonne - im Winter Vitamin D. ÄrzteZeitung 2009. Online: http://www.aerztezeitung.de/medizin/ krankheiten/skelett_und_weichteilkrankheiten/article/571566/ 10-minuten-täglich-sonne-winter-vitamin-d.html; last access: 01.03.2017

[37] Sunshine-Vitamin-Alliance. Sun exposure to the skin is the human race's natural, intended, most effective and most neglected source of vitamin D. 2007. Online: http://www.sunshinevitamin.org/; last access: 01.03.2017

[38] Holick MF. Vitamin D deficiency. N Engl ] Med 2007; 357: 266-281

[39] O'Donnell S, Cranney A, Horsley T et al. Efficacy of food fortification on serum 25-hydroxyvitamin D concentrations: systematic review. Am J Clin Nutr 2008; 88: 1528-1534

[40] Houston DK, Cesari M, Ferrucci L et al. Association between vitamin D status and physical performance: the InCHIANTI study. J Gerontol A Biol Sci Med Sci 2007; 62: 440-446 
[41] Wanner M, Richard A, Martin B et al. Associations between objective and self-reported physical activity and vitamin D serum levels in the US population. Cancer Causes Control 2015; 26: 881-891

[42] Yoshioka M, Ayabe M, Yahiro T et al. Long-period accelerometer monitoring shows the role of physical activity in overweight and obesity. Int J Obes (Lond) 2005; 29: 502-508

[43] Hemmingsson E, Ekelund U. Is the association between physical activity and body mass index obesity dependent? Int J Obes (Lond) 2007; 31: 663-668

[44] Vanlint S. Vitamin D and obesity. Nutrients 2013; 5: 949-956

[45] Compston JE, Vedi S, Ledger JE et al. Vitamin D status and bone histomorphometry in gross obesity. Am J Clin Nutr 1981; 34: 2359-2363

[46] Park J, Gong J, Hong $\mathrm{H}$ et al. Serum Vitamin D status and its relations to body fatness and fitness and risk factors in young adults. J Exerc Nutrition Biochem 2013; 17: 143-150

[47] Vimaleswaran KS, Berry DJ, Lu C et al. Causal relationship between obesity and vitamin D status: bi-directional Mendelian randomization analysis of multiple cohorts. PLoS Med 2013; 10: e1001383

[48] Parkin DM, Boyd L. 8. Cancers attributable to overweight and obesity in the UK in 2010. Br J Cancer 2011; 105 (Suppl. 2): S34-S37

[49] Russo J, Russo IH. The role of estrogen in the initiation of breast cancer. J Steroid Biochem Mol Biol 2006; 102: 89-96

[50] Key T], Appleby PN, Reeves GK et al.; Endogenous Hormones Breast Cancer Collaborative Group. Body mass index, serum sex hormones, and breast cancer risk in postmenopausal women. J Natl Cancer Inst 2003; 95: $1218-1226$

[51] Brisson J, Morrison AS, Kopans DB et al. Height and weight, mammographic features of breast tissue, and breast cancer risk. Am J Epidemiol 1984; 119: 371-381

[52] Sala E, Warren R, McCann J et al. High-risk mammographic parenchymal patterns and anthropometric measures: a case-control study. $\mathrm{Br}$ J Cancer 1999; 81: 1257-1261
[53] Boyd N, Martin L, Stone ] et al. A longitudinal study of the effects of menopause on mammographic features. Cancer Epidemiol Biomarkers Prev 2002; 11 (10 Pt 1): 1048-1053

[54] Checka CM, Chun JE, Schnabel FR et al. The relationship of mammographic density and age: implications for breast cancer screening. AJR Am J Roentgenol 2012; 198: W292-W295

[55] Boyd NF, Dite GS, Stone J et al. Heritability of mammographic density, a risk factor for breast cancer. N Engl J Med 2002; 347: 886-894

[56] Martin L], Melnichouk O, Guo H et al. Family history, mammographic density, and risk of breast cancer. Cancer Epidemiol Biomarkers Prev 2010; 19: 456-463

[57] Ziv E, Shepherd J, Smith-Bindman R et al. Mammographic breast density and family history of breast cancer. J Natl Cancer Inst 2003; 95: 556-558

[58] Bérubé S, Diorio C, Mâsse B et al. Vitamin D and calcium intakes from food or supplements and mammographic breast density. Cancer Epidemiol Biomarkers Prev 2005; 14: 1653-1659

[59] Thomson CA, Arendell LA, Bruhn RL et al. Pilot study of dietary influences on mammographic density in pre- and postmenopausal Hispanic and non-Hispanic white women. Menopause 2007; 14: 243-250

[60] Vachon CM, Kushi LH, Cerhan JR et al. Association of diet and mammographic breast density in the Minnesota breast cancer family cohort. Cancer Epidemiol Biomarkers Prev 2000; 9: 151-160

[61] Diorio C, Bérubé S, Byrne C et al. Influence of insulin-like growth factors on the strength of the relation of vitamin $D$ and calcium intakes to mammographic breast density. Cancer Res 2006; 66: 588-597

[62] Chai W, Maskarinec G, Cooney RV. Serum 25-hydroxyvitamin D levels and mammographic density among premenopausal women in a multiethnic population. Eur J Clin Nutr 2010; 64: 652-654

[63] Knight JA, Vachon CM, Vierkant RA et al. No association between 25-hydroxyvitamin D and mammographic density. Cancer Epidemiol Biomarkers Prev 2006; 15: 1988-1992

[64] Neuhouser ML, Bernstein L, Hollis BW et al. Serum vitamin D and breast density in breast cancer survivors. Cancer Epidemiol Biomarkers Prev 2010; 19: 412-417 